\title{
Relationships between Rutting Behaviour and Non-annual Incisor Dentine Layers of Male Sika Deer - A Hypothesis
}

\author{
ZACHOWANIE RUJOWE A NIECYKLICZNE ODKŁADANIE SIE WARSTW DENTYNY \\ W SIEKACZACH SAMCÓW JELENI SIKA - HIPOTEZA
}

Luděk BARTÓS, Vladimír MALIK ${ }^{1}$, Jaromír HYÃNEK, Jiří VAVRUNĚK ${ }^{2} \&$ Milan BYTEŠNIK ${ }^{3}$

\begin{abstract}
Bartoš L., Malík J., Hyánek J., Vavruněk J. \& Bytešník M., 1984: Relationships between rutting behaviour and non-annual incisor dentine layers of males sika deer - a hypothesis. Acta theriol., 29, 35: 431-435

In a previous study a comparison was made between methods of age determination in male sika deer. The number of cement layers in the first molar and the number of secondary dentine layers in histological sections of the first incisor were assessed. In only 10.34 per cent were the numbers of layers in the incisor and the molar equal. A hypothesis is put forward that the mentioned differences in the numbers of layers are caused by social activity of the male during rutting season. Presumably the highest ranking males having the lowest number of surplus layers. Some indirect data are presented to support the hypothesis.

[Department of Genetics, Research Institute of Animal Production, CS-251 61 Praha 10-Uhř́něves. Czechoslovakia]
\end{abstract}

In a previous study a comparison was made between methods of age determination in male sika deer (Cervus nippon Temminck, 1938). The number of cement layers in the first molar and the number of secondary dentine layers in histological sections of the first incisor were assessed. In agreement with findings of other authors (Morris, 1972) the values generated by these methods were different in many cases. In only 3 out of 29 instances were the numbers of layers in the incisor and the molar equal. In 14 cases the number of dentine layers in the incisor was double the number of cement layers in the molar, in 10 cases the number of dentine layers was 3 times the number of cement layers and in 2 cases the number of dentine layers was 4 times the number of cement layers (Bartoš et al., 1984). Photographs of these subjects are included in the paper by Bartoš et al. (1984).

In several cervid species, authors have reported more cement layers than usual for that age of animal. Additional layers are usually referred to as "surplus" layers and have been recorded in mule deer (Odocoileus hemionus) (Low \& Cowan, 1963), red deer (Cervus elaøhus) (Mitchell, 1967), white-tailed deer (O. virginianus) (Sauer, 1973 cited by Gasaway et al., 1978; Rice, 1980), and reindeer (Rangifer tarandus) (Reimers \&

Authors addresses: ${ }^{1}$ Laboratory of Neurohistology, Institute of Physiology CAS, Albertov 5, CS-128 00 Praha 2; 2 State Forests of West Bohemia, Slovanská alej 36, CS-317 54 Plzeň; ${ }^{3}$ Dimitrovo nám. 17, CS-170 00 Praha 7, Czechoslovakia. 
Nordby, 1968; Leader-Williams, 1979). The origin of these surplus layers has not been fully explained yet. Some authors (eg. Mitchell, 1967; Reimers \& Nordby, 1968, etc.) refer to these layers as "rut" l'ayers, suggesting a connection between their production and the sharp annual increase in social activity in deer.

Klevezal (1973) postulated that dentine and/or cement layers are formed in teeth and bones during periods of fasting, reduced food integer or low quality forage intake during adverse climatic conditions which results in a reduction in growth rate.

Active rutting behaviour in a male deer leads usually to physical exhaustion and hence a decrease in physical condition (Gibson \& Guinness, 1980). Presumably the more subordinate male sika deer is l'ess likely to actively participate in the rut and therefore remain in better physical condition. However, the annual changes in physical condition in deer which occur during autumn and winter are a complex phenomenon influenced by hormonal and nutritional state (Kay, 1979). This paper aims to explaine the formation of surplus dentine layers.

Ashby \& Henry (1979) found in roe deer (Capreolus capreolus) that the formation of cement layers during winter begins earlier in incisors than in molars. If this is true also for incisor dentine and for other cervid species, one could assume that rutting activity in European sika deer which occur in mid/late autumn (Bartoš \& Žirovnický, 1982) would correlate with the beginning of formation of winter dentine layers. A hypothesis is put forward that in sika deer the reduced food intake and/or hormonal changes induced by rutting activity may be manifested by winter dentine layer formation. If rutting is over before winter dentine formation begins, summer dentine growth may continue if sufficient food is available leading to additional growth in incisor teeth. This is in accordance with Reimers \& Nordby (1968) who suggested surplus "rut" cement layers in reindeer coming from areas of abundant vegetation but not in reindeer from less suitable areas.

As in red deer (Pollock, 1975) probably also in sika deer the seasonal elevation in testosterone level followed by rutting activity may be accompanied by a lower food intake. High ranking males show a greater increase in testosterone level (Brain, 1980; Bartoš, 1980) which may lead to an even lower food intake (Pollock, 1975). Silberberg \& Silberberg (1971) reported high testosterone levels had an inhibitory influence on bone tissue growth in humans and a similar effect was found in white-tailed deer (Brown et al., 1978). Thus presumably the formation of winter dentine layers may be triggered by high testosterone levels and rutting activity in high ranking males and may be maintained until normal restricted winter feeding conditions appears. In subordinate animals winter dentine formation may begin with the onset of rutting too. The reduction of testosterone after social suppression by the more dominant animals, however, may remove the inhibitory effect on bone tissue growth and growth of the previous summer dentine layers may continue. Subordinate stags usually wander between different rutting stands (Yevtushevskiy, 1974) and therefore the level' of "social stress" in these animals may fluctuate significantly several times during a short period of time. The consequent hormonal changes may be reflected 
in an irregular pattern of dentine formation. Presumably, the most subordinate males may have the highest number of surplus incisor layers while high ranking males should show a reduction in the formation of surplus dentine layers as their rank increases.

To test the hypothesis, indirect data were used as behavioural records were unavailable. Three areas of study were considered (1) It has been recorded in red deer that social rank increases with age in stags (Appleby, 1980; Bartoš \& Hyánek, 1982a). One would predict a negative correlation between the proportion of surplus incisor dentine layers and age in male sika deer if the hypothesis is true. (2) In cervids, age and body size are usually correlated with social rank (Clutton-Brock et al., 1979; Suttie, 1980). One would also predict a negative correlation between surplus incisor dentine layers and body weight. (3) In red deer stags, a close relationship has been found between social position during the velvet period and length, weight and number of points on a growing anler (Bartoš \& Hyánek, 1982a). A negative correlation between proportion of surplus incisor dentine layers and the length, weight, and number of points on an antler would support this hypothesis. However. since antler weight is not obtainable directly as the trophy includes the skull of the animal, the "antler weight index" (AWI) which showed close correlation with antl'er weight in red deer (unpublished obs.) was used.

Male sika deer shot between 1 September and 30 December during the period 1976-1980 in the region of West Bohemia, Czechoslovakia, were used for the study. Carcasses were weighted and antlers measured. Analysis involved 29 specimens. The following measurements were taken: a) Length of main beam (from coronet to the farthest tine); b) Numbe of antler points; c) AWI value was calculated using the formula

$$
\mathrm{AWI}=\frac{\text { length of main beam } \times\left(\text { average circumference of beam) }{ }^{2}\right.}{4 \pi}
$$

Here the average circumference of the beam was the arithmetic mean of the lower circumference (measured between the brow and the trez tine) and the upper circumference (measured between the trez tine and the terminal fork). In all cases, the value used in the analysis was an average for both antlers.

The age of each subiect was estimated by counting the cement layers according to the modified method used by Mitchell $(1963 ; 1967)$ and described in Bartoš et al. (1984). The preparation method for histological sections of incisors are also described in the parallel study (Bartoš et al., 1984). The proportion of surplus incisor dentine layers was calculated using the formula:

$\begin{aligned} & \text { Proportion of dentine } \\ & \text { to cement layers }(\%)\end{aligned}=\frac{\text { Number of incisor dentine layers }}{\text { Number of molar cement layers }} \times 100$

1) A significant negative correlation was found between the proportion of incisor dentine layers to molar cement layers and age $(r=-0.67, P<0.001)$. 2) A significant negative correlation was found between the proportion of incisor dentine layers to molar cement layers and body weight $(r=-0.37, P<0.05)$. 3) A significant negative cor- 
relation was found between the proportion of incisor dentine to molar cement layers and the AWI $(r=-0.53, P<0.01)$ and antler length $(r=-0.37, P<0.05)$. But a non-significant correlation was found between the number of antler points and proportion of incisor dentine layers to molar cement layers $(r=-0.13, \mathrm{NS})$.

The results support the hypothesis in four out of five cases. The failure to find a significant correlation between the number of antler points and proportion of surplus dentine to cement layers may be true only in sika deer. The male sika deer develop only 4 points on each antler in both Europe (Bartoš \& Žirovnický, 1981) and their native land, Japan (Imaizumi, 1970; Whitehead, 1972) by the age of three or four years. In this study 75.7 per cent of the subjects has 4 points. Hence no relationship would occur between the number of points, rutting activity and number of surplus incisor dentine layers. The results of correlation between antler characteristics and surplus dentine layers may be influenced by the fact that antler size during the rut is only a rough estimate of potential dominance. As in red deer (Bartoš \& Hyánek, $1982 \mathrm{~b})$ rank success and antler size durnig the rut in sika deer depend on many ethological and environmental factors.

The results confirm the advanced hypothesis and lead one to conclude that the greater the amount of social activity a male sika deer parcipitates in, the lower the number of surplus incisor dentine layers. The formation of seasonal cement rest lines in cervids of temperate latitude may begin in January or February (Ashby \& Henry, 1979; Mitchel, 1963; 1967) after the end of rutting season. The formation of rut cement lines in molar teeth would therefore be less than in dentine of incisors.

The formation of dentine/cement layers is influenced by several factors (e.g. food, climate, etc.), rutting may be only one of many influences which affects the correlation of the number of layers and age. In cases where annual layers are missing (e.g. Lowe, 1967) the rut has probably minimal influence on dentine/cement formation.

This study should be regarded as tentative. Further investigation should involve the study of nutritional, hormonal and social factors and their times of action, in isolation and combined, on formation of annual layers in incisors and molars.

Acknowledgements: The authors thank Miss Gill Albiston for her kind help with the English version of the manuscript.

\section{REFERENCES}

Appleby M. C., 1980: Social rank and food access in red deer stags. Behaviour, 74: 294-309. - Ashby K. R. \& Henry B. A. M., 1979: Age criteria and life) expectancy of roe deer (Capreolus capreolus) in coniferous forest in North-Eastern England. J. Zool., 189: 207-220. - Bartoš L., 1980: The date of antler casting, age and social hierarchy relatinships in the red deer stag. Behav. Process., 5: 293-301. - Bartoš L. \& Hyánek J., 1982a: Social position in the red deer stag I The effect on developing antlers. [In: R. D. Brown (ed.) "Antler development in Cervidae"]. Caesar Kleberg Wildl. Res. Ins.: 451-461, Kingsville. - Bartoš L. \& Hyánek J., 1982b: Social position in the red deer stag II. The relationship with developed antlers. [In: R. D. Brown (ed.) "Antler development in Cervidae"]. Caesar Kleberg Wildl. Res. Inst: 463-466, Kingsville. - Bartoš L., Vavruněk J., 
Bytešník M., Malík V. \& Hyánek J., 1984: Odhad věku zvěře sika podle vrstev zubního cementu. Folia Venat., in press. - Bartoš L. \& Žirovnický J., 1981: Hybridization between red and sika deer II. Phenotype analyses. Zool. Anz, 207: 271-278. - Bartoš L. \& Žirovnický J., 1982: Hybridization between red and sika deer III. Interspecific behaviour. Zool. Anz., 208: 20-36. - Brain P. F., 1980: Adaptive aspects of hormonal correlates of attack and defence in laboratory mice - a study in ethobiology. [In: P. S. McConnell, G. J. Boer, H. J. Romijn, N. E. Vandepoll \& M. A. Corner (eds.) "Adaptive capabilities of the nervous system"]. Elsevier North-Holland Biomedical Press: 391-413, Amsterdam. Brown R. D., Cowan R. L. \& Griel L. C., 1978: Correlation between antler and long mass and circulating androgens in white-tailed deer (Odocoileus virginianus). Amer. J. Vet. Res., 39: 1053-1056. - Clutton-Brock T. H., Albon S. D., Gibson R. M. \& Guinness F. E., 1979: The logical stag: Adaptive aspects of fighting in red deer (Cervus elaphus L.). Anim. Behav., 27: 211-225. - Gasaway W. C., Harkness D. B. \& Rasch R. A., 1978: Accuracy of moose age determination from incisor cementum layers. J. Wildl. Mgmt., 42: 558-563. - Gibson R. M. \& Guinness F. E., 1980: Differential reproduction among red deer (Cervus elaphus) stags on Rhum. J. Anim. Ecol., 49: 199-208. - Imaizumi Y., 1970: Description of a new species of Cervus from the Tsushima Islands, Japan, with a revision of the subgenus Sika based on clinal analysis. Bull. Nat. Sci. Mus. Tokyo, 13: 185-194. Kay R. N. B., 1979: Seasonal changes of apetite in deer and sheep. ARC Res. Rev., 5: 13-15. - Klevezal G. A., 1973: Ob ograničenijah i novyh vozmožnostijah ispolzovanija vozrasta mlekopitajuščih. Zool. Ż., 5z: 757-765. - Leader-Williams N., 1979: Age determination of reindeer introduced into South Georgia. J. Zool., 188: 501-515. - Low W. A. \& Cowan I. McT., 1963: Age determination of deer annual structure of dental cementum. J. Wildl. Mgmt., 27: 466-471. - Lowe V. P. W., 1967: Teeth as indicators of age with special references to red deer of known age from Rhum. J. Zool., 152: 137-153. - Mitchell B., 1963: Determination of age in Scottish red deer from growth layers in dental cement. Nature, 198: 350-351. - Mitchell B., 1967: Growth layers in dental cement for determining the age of red deer (Cervus elaphus). J. Anim. Ecol., 36: 279-293. - Morris P., 1972: A review of mammalian age determination methods. Mammal Rev., 2: 69-104. - Pollock A. M., 1975: Seasonal changes in apetite and sexual condition in red deer stags maintained on a six-month photoperiod. J. Physiol., 244: 95-96P. - Reimers E. \& Nordby O., 1968: Relationship between age and tooth cementum layers in Norwegian reindeer. J. Wildl. Mgmt., 32: 957-961. - Rice L. A., 1980: Influences of irregular dental cementum layers on aging deer incisors. J. Wildl. Mgmt., 44: 266-268. - Silberberg M. \& Silberberg R., 1971: Steroid hormones and bone. [In: G. Bourne (ed.) "The biochemistry and physiology of bone"]. Academic Press: 401-479, New York. - Suttie J. M., 1980: The effect of antler removal on dominance and fighting behaviour in farmed red deer stags. J. Zool., 190: 217-224. - Whitehead G. K., 1972: Deer of the world. Constable and Co., London. - Yevtushevskiy N. N., 1974: Razmnoženie olenija pjatnistogo (Cervus nippon hortulorum Sw.) v uslovijah Pridneprovija. Vestn. Zool., 8: 23-28.

Accepted, June 6, 1984. 